\title{
Competition for nitrogen by three sympatric species of Eucalyptus
}

\author{
Emma M. PAUlding ${ }^{1,2}$, Alan J.M. BAKER ${ }^{3}$, Charles R. WARREN ${ }^{1,4 *}$ \\ ${ }^{1}$ School of Forest and Ecosystem Science, The University of Melbourne, Water Street, Creswick VIC 3363, Australia \\ ${ }^{2}$ Elmoby Ecology. 24 Main Rd, Smeaton VIC 3364, Australia \\ ${ }^{3}$ School of Botany, The University of Melbourne, Parkville, VIC 3010, Australia \\ ${ }^{4}$ School of Biological Sciences, The University of Sydney, NSW 2006, Australia
}

(Received 21 May 2009; revised version 5 October 2009; accepted 9 October 2009)

Keywords:

Eucalyptus /

nitrogen /

uptake /

amino acid /

competition
Mots-clés :

Eucalyptus /

azote /

absorption /

acide aminé /

compétition

\begin{abstract}
- Nitrogen $(\mathrm{N})$ exists in the soil in a variety of different forms and thus plants may avoid competition by taking up $\mathrm{N}$ as different chemical forms.

- This study examined the uptake of nitrate, ammonium and glycine by three co-occurring species of Eucalyptus (E. obliqua, E. radiata and E. rubida) from dry sclerophyll forest in south-eastern Australia. Species preference for $\mathrm{N}$ forms was determined by measuring uptake of glycine, nitrate and ammonium from ${ }^{15} \mathrm{~N}$-labelled solutions containing equimolar $100 \mu \mathrm{mol} \mathrm{L}{ }^{-1}$ concentrations of all three $\mathrm{N}$ forms. $\mathrm{KCl}$ extracts were used to assess the relative abundance of the different forms of $\mathrm{N}$ in the soil's exchangeable pool.

- $\mathrm{KCl}$ extracts of soil indicated that amino acids comprised $30-40 \%$ of the soluble non-protein $\mathrm{N}$, while ammonium varied from $10-70 \%$ and nitrate from $5-70 \%$. In all species, ammonium was the preferred source of nitrogen and was taken up 2.5-4.5 times faster than glycine, and 30-50 times faster than nitrate. Species did not differ in preference for $\mathrm{N}$-forms (species* $\mathrm{N}$-form interaction, not significant).

- This study indicates that nitrate, ammonium and amino acids are all present in soil, and thus there is the potential for niche differentiation based on chemical forms of $\mathrm{N}$. However, there is no evidence that co-occurring Eucalyptus avoid competition for $\mathrm{N}$ by taking up different chemical forms.
\end{abstract}

Résumé - Compétition pour l'azote par trois espèces d'Eucalyptus sympatriques.

- L'azote $(\mathrm{N})$ existe dans le sol sous une variété de formes différentes et donc les plantes peuvent éviter la concurrence en absorbant $\mathrm{N}$ depuis différentes formes chimiques.

- Cette étude a porté sur l'assimilation du nitrate, de l'ammonium et de la glycine par trois espèces d'eucalyptus co-occurentes (E. obliqua, E. radiata et E. rubida) de la forêt sclérophylle sèche dans le sud-est de l'Australie. La préférence des espèces pour les formes de $\mathrm{N}$ a été déterminée en mesurant l'absorption de la glycine, du nitrate et de l'ammonium à partir de solutions marquées ${ }^{15} \mathrm{~N}$ contenant des concentrations équimolaires de $100 \mu \mathrm{mol} \mathrm{L}^{-1}$ de toutes les trois formes de $\mathrm{N}$. Des extraits de $\mathrm{KCl}$ ont été utilisés pour évaluer l'abondance relative des différentes formes de $\mathrm{N}$ dans le pool échangeable du sol.

- Les extraits de $\mathrm{KCl}$ du sol ont indiqué que les acides aminés étaient constitués de 30-40\% de non protéines $\mathrm{N}$ solubles, tandis que l'ammonium variait de 10-70\% et les nitrates de 5-70\%. Chez toutes les espèces, l'ammonium était la source privilégiée d'azote et a été absorbé $2.5-4.5$ fois plus vite que la glycine, et 30-50 fois plus vite que les nitrates. Les espèces ne diffèrent pas dans leur préférence pour les formes d'azote (interaction espèces*formes d'azote, non significative).

- Cette étude indique que les nitrates, l'ammonium et les acides aminés sont tous présents dans le sol, et donc il y a le potentiel pour la différenciation de niches, basées sur des formes chimiques de N. Toutefois, il n'existe aucune preuve que les espèces co-occurentes d'Eucalyptus évitent la compétition pour l'azote en absorbant différentes formes chimiques.

\footnotetext{
*Corresponding author: Charles.warren@bio.usyd.edu.au
} 


\section{INTRODUCTION}

The co-occurrence of numerous plants species in a community is somewhat puzzling given the remarkable similarity of their fundamental niches. That is, all species require light, nutrients and water. Co-existence of species despite their (broadly similar) fundamental niches may be because competition has resulted in species occupying distinct realised niches (Hutchinson, 1959; MacArthur and Levins, 1967). Niches may be separated temporally or spatially among species (e.g., rooting depth, Parrish and Bazzaz, 1976). In the case of nitrogen $(\mathrm{N})$, realised niches may differ because plants take up different chemical forms of N (McKane et al., 2002; Miller et al., 2007; Näsholm et al., 1998).

To determine the potential for niche differentiation it is necessary to determine which of the many forms of $\mathrm{N}$ in soil are taken up by plants. It was thought that plants could only take up inorganic $\mathrm{N}$, but recent studies indicate that plants can directly take up significant quantities of organic $\mathrm{N}$, especially simple forms such as amino acids (Chapin et al., 1993; Schimel and Bennett, 2004). This idea is, in fact, not new with reports of amino acid uptake stretching back more than four decades (Wright, 1962). What is new is recognition that uptake of amino acids occurs in soil, not just in laboratory experiments, and that uptake of amino acids is not restricted to plants from cool and wet habitats. For example, uptake of amino acids from soil has been shown in species from temperate habitats such as Eucalyptus spp. (Warren, 2009a; 2009b).

Several studies have shown that realised niches differ among co-occurring plants, by way of species taking up different chemical forms of N. For example, plants from arctic tundra differed in the form of $\mathrm{N}$ acquired with more productive species taking up more abundant forms of $\mathrm{N}$, while less productive species took up less abundant forms of $\mathrm{N}$ (McKane et al., 2002). In an alpine dry meadow the presence and identity of neighbours affected the forms of $\mathrm{N}$ taken up; implying that plasticity in uptake of different $\mathrm{N}$ forms may help plants avoid competition (Miller et al., 2007). In contrast to these and other studies demonstrating niche differentiation (e.g. Miller and Bowman, 2003; Weigelt et al., 2003; 2005), other studies have reported co-occurring species with similar preferences for $\mathrm{N}$ forms (Kronzucker et al., 1997; Stewart et al., 1989).

This study examines the uptake of different forms of nitrogen by three co-occurring, co-dominant species of mature Eucalyptus (E. obliqua, E. radiata and E. rubida) growing in an undisturbed dry sclerophyll forest in south-eastern Australia. We suspect that $\mathrm{N}$ is limiting in this ecosystem because soil C:N ratios are 30-35 (Warren, unpublished data) and thus soil microbes should be net immobilizers of $\mathrm{N}$ (Hodge et al., 2000). In the absence of niche differentiation, the species ought to be especially intense competitors for $\mathrm{N}$ given that they co-occur and are ecologically and taxonomically similar. Hence, this study provides a useful test for the theory of niche differentiation based on $\mathrm{N}$ forms, and is the first such study with Eucalyptus. Glycine was chosen as a representative amino acid because it is common in soil extracts from Eucalyptus woodland (Warren, 2008), has been used extensively in previous studies, and may be especially important for plant up- take because it is a poor substrate for microbial growth (Lipson et al., 1999). Attached, intact roots were supplied with each of the three $\mathrm{N}$ forms at concentrations of $100 \mu \mathrm{mol} \mathrm{N} \mathrm{L}{ }^{-1}$. Double-labelled glycine $\left({ }^{13} \mathrm{C}_{2}^{15} \mathrm{~N}\right.$-glycine $)$ was used to determine whether glycine was taken up as an intact molecule or after mineralisation (Nasholm and Persson, 2001; Warren, 2006). Specific aims were to examine whether three Eucalyptus species occupy different niches by taking up different chemical forms of $\mathrm{N}$. To place these data in the broader context of which forms of $\mathrm{N}$ are in the soil, we assessed the relative availability of the different $\mathrm{N}$ forms in the soil with $\mathrm{KCl}$ extracts.

\section{MATERIAL AND METHODS}

\subsection{Study sites and experimental design}

This study was conducted in the Wombat State Forest (Lat $37^{\circ}$, Long $144^{\circ}, 600-700 \mathrm{~m}$ altitude). We chose three of five sites established in 1984 (Tolhurst and Flinn, 1992) based on accessibility in winter and presence of all three dominant species. The three sites are separated from each other by at least $10 \mathrm{~km}$ and all were protected from fire and logging disturbance for at least $50 \mathrm{y}$. Each of the three sites are dry sclerophyll forest co-dominated by messmate $(E u-$ calyptus obliqua L'Hérit), candlebark (E. rubida Deane \& Maiden) and narrow-leaf peppermint (E. radiata Sieber ex DC). The diameter at breast height of each of the Eucalyptus species was $>40 \mathrm{~cm}$. The lower stratum has a sparse covering of grasses (Poa sieberiana), sedges (Lomandra filiformis), bracken (Pteridium esculentum) and small herbs such as Viola, Gonocarpus and Goodenia. The soil is primarily yellow podsolic soils derived from Ordovician sedimentary rocks and the climate is cool temperate with the majority of the 900$925 \mathrm{~mm}$ of annual rainfall in winter and spring. Details on soil chemistry have been published previously (Tomkins et al., 1991).

Measurements of pools of $\mathrm{N}$ in soil and $\mathrm{N}$ uptake by trees were made on three trees of each of the three species at each of the three sites on four field trips (May, August and October 2006; January 2007) (i.e. 4 dates $\times 3$ sites $\times 3$ species $\times 3$ reps). On each field trip we selected a different set of trees. In all cases trees were co-dominant or dominant (based on diameter at breast height $>40 \mathrm{~cm}$ ).

\subsection{Nitrogen uptake by trees}

Nitrogen uptake was determined using intact roots exposed to isotope-labelled hydrosolutions $\left({ }^{15} \mathrm{~N}\right.$ uptake by roots in a liquid solution, Lucash et al., 2007) essentially as described previously (Warren and Adams, 2007). Plants were offered simultaneously all three $\mathrm{N}$ sources (60 atom\% ${ }^{15} \mathrm{NO}_{3}^{-}, 60$ atom\% ${ }^{15} \mathrm{NH}_{4}^{+}, 99$ atom\% ${ }^{13} \mathrm{C}_{2}^{15} \mathrm{~N}$-glycine; all from Isotec Inc., Miamisburg, OH, USA), at $100 \mu \mathrm{molNL} \mathrm{N}^{-1}$ each so as to provide a "choice" of different $\mathrm{N}$ sources. Equimolar mixtures were used because there may be interactions between uptake of one form of $\mathrm{N}$ and uptake of other forms (Persson et al., 2006). For example, ammonium inhibits uptake of nitrate (e.g. Gessler et al., 1998; Kamminga-Van Wijk and Prins, 1993), while the amino acid glycine can inhibit uptake of nitrate and ammonium (Henry and Jefferies, 2003). In practice, this meant three uptake solutions differing only in which $\mathrm{N}$ source was ${ }^{15} \mathrm{~N}$ labelled. In addition to $\mathrm{N}$, uptake solutions contained $10 \mathrm{mg} \mathrm{L}^{-1}$ ampicillin (to minimise microbial activity) and $100 \mu \mathrm{mol} \mathrm{L}^{-1} \mathrm{CaCl}_{2} \cdot 2 \mathrm{H}_{2} \mathrm{O}$ was added 
for membrane stability. Preliminary experiments showed that ampicillin was necessary to prevent rapid de-amination of uptake solutions (Warren, unpublished data). Solutions were prepared with type 1 ultra-pure water with a resistivity of $18.2 \mathrm{M} \Omega$.

Large roots were unearthed at the base of each tree and followed out to find healthy fine roots less than $4 \mathrm{~mm}$ in diameter within $1 \mathrm{~m}$ of the tree base. Six roots per tree were unearthed, three for controls, and three for the uptake of nitrogen. Roots were carefully brushed clean from soil and the three control roots were severed and rinsed with $50 \mathrm{mM} \mathrm{KCl}$ and deionised water, dried and placed into labelled envelopes. The other three roots were left attached to the tree and were placed in $15 \mathrm{~mL}$ plastic centrifuge tubes containing the three uptake solutions. The tubes were pushed into the soil for stability and the roots were left in solution for 1.5-2 h. After immersion, roots were cut at the level of submersion, and a $3-4 \mathrm{~cm}$ segment above the submersion level was also collected to test whether labelled $\mathrm{N}$ had been transported out of the immersed root segment. Roots were washed with $50 \mathrm{mM} \mathrm{KCl}$, then deionised water, and placed into labelled envelopes for drying. Roots were rinsed with $\mathrm{KCl}$ to ensure that the presence of labelled nitrogen and carbon was not due to labelled molecules remaining in the apoplast, or within rhizosphere micro-organisms. Roots were dried at $80{ }^{\circ} \mathrm{C}$ for $4 \mathrm{~d}$, weighed and then ground to a fine powder with a matrix mill (Retsch Mixer Mill MM301, Germany). Isotope ratios and contents of carbon and nitrogen were determined by continuous flow isotope-ratio mass spectrometry (EuroEA 3028HT, EuroVector SpA, Milan, Italy; and IsoPrime, GV Instruments Manchester, UK).

$\mathrm{N}$ uptake was calculated from the enrichment of ${ }^{15} \mathrm{~N}$ and ${ }^{13} \mathrm{C}$ compared to control roots. Values of atom percent and concentrations of $\mathrm{C}$ and $\mathrm{N}$ of roots were used to calculate moles excess of ${ }^{15} \mathrm{~N}$ and ${ }^{13} \mathrm{C}$. Uptake rate was calculated per unit root dry mass (i.e. $\mu \mathrm{mol} \mathrm{N}$ $\mathrm{g}^{-1} \mathrm{DM} \mathrm{h}^{-1}$ ). Previous experiments using seedlings pre-treated with the protonophore carbonyl cyanide $m$-chlorophenylhydrazone established that "passive" uptake is less than $10 \%$ of $\mathrm{N}$ taken up (Warren, unpublished data). Hence, rates of uptake reported here represent true uptake rather than "passive" uptake that might occur, e.g., following damage of roots, due to adsorption of ${ }^{15} \mathrm{~N}$-label to root surfaces, or due to contamination.

Analysis of samples collected in May and August indicated that the 3-4 cm segment collected from above the immersed segment did not contain significant ${ }^{15} \mathrm{~N}\left(-0.11 \pm 0.22 \mu \mathrm{g}{ }^{15} \mathrm{~N}\right.$; mean $\left.\pm \mathrm{SE}, n=139\right)$ compared with the immersed segment of root $\left(4.18 \pm 0.46 \mu{ }^{15} \mathrm{~N}\right.$; $n=151)$. This indicated that no significant ${ }^{15} \mathrm{~N}$ was being transported out of the immersed segment of root, and thus calculations would be unaffected by including the upper (un-immersed) segment in calculations. For these reasons, all calculations were based solely on ${ }^{15} \mathrm{~N}$ uptake by the immersed segment of root and the upper (unimmersed) segments were not collected at the two subsequent field trips (October and January).

\subsection{Collection and extraction of soil samples}

Soil was extracted with $1 \mathrm{M} \mathrm{KCl}$ to determine the relative proportions of nitrate, ammonium and amino acids. This procedure is a useful indicator of the relative proportions of the different $\mathrm{N}$ forms that are adsorbed and/or exchangeable and potentially available for plant uptake (Schobert and Komor, 1987). We collected soil samples adjacent to each tree used to measure $\mathrm{N}$ uptake, at each of the three sites, on each of the 4 measurements dates (i.e. 4 dates $\times 3$ sites $\times$ 3 species $\times 3$ reps). Soil samples $(0-10 \mathrm{~cm}$ depth) were collected on the same day as nitrogen uptake was determined from within $3 \mathrm{~m}$ of the base of trees used to determine $\mathrm{N}$ uptake. At each tree we collected three separate samples, which were subsequently combined to give one composite sample. Soils were sieved to $2 \mathrm{~mm}$ in the field to remove stones and larger aggregates of soil. Soil were transported to the laboratory and stored at $4{ }^{\circ} \mathrm{C}$ for no more than $48 \mathrm{~h}$ before they were processed.

One sub-sample of fresh soil was extracted with $1.0 \mathrm{M} \mathrm{KCl}$ solution (6 g soil:30 $\mathrm{mL} \mathrm{KCl}$ ) by shaking at $100 \mathrm{rpm}$ for $90 \mathrm{~min}$. Ammonium and nitrate concentrations of $\mathrm{KCl}$ extracts were determined by segmented flow analysis (Bran and Luebbe, Hamburg, Germany). Total amino acids in soil extracts were determined by the ninhydrin method (Moore, 1968; Jones et al., 2002). To avoid the problem of ninhydrin reacting not just with amino acids but also with ammonium; ammonium was removed from $\mathrm{KCl}$ extracts by adding magnesium oxide to volatilise ammonium as ammonia.

A second sub-sample of soil was weighed, dried at $105^{\circ} \mathrm{C}$ for $48 \mathrm{~h}$ and re-weighed to determine dry weight:wet weight ratio. A third sub-sample of soil was dried at $80{ }^{\circ} \mathrm{C}$ for $48 \mathrm{~h}$, and then ground into a fine powder with a matrix mill (Retsch Mixer Mill MM301, Germany) and analysed for total $\mathrm{N}$ and $\mathrm{C}$ by Dumas combustion (LECO Corporation, Michigan, USA).

\subsection{Statistical analysis}

The significance of differences among treatments were determined using an analysis of variance (ANOVA), with date, site, species and $\mathrm{N}$ form as factors. Where differences were significant, a LSD post hoc test determined differences between pairs of means. Analysis of covariance (ANCOVA) with ${ }^{15} \mathrm{~N}_{\text {excess }}$ as covraiate was used to determine if the relationship between ${ }^{15} \mathrm{~N}_{\text {excess }}$ and ${ }^{13} \mathrm{C}_{\text {excess }}$ differed between dates, sites or species. Data sets were checked for normality and transformed as appropriate. All statistics were performed with Minitab Release 14.1.

\section{RESULTS}

\subsection{Pools of $\mathrm{N}$ in $\mathrm{KCl}$ extracts of soil}

Neither absolute nor relative concentrations of $\mathrm{N}$-forms differed among the three sites, or among the three tree species they were adjacent to (ANOVA, $P>0.05$ ). Hence, data for sites and species are combined. Pools of nitrate and ammonium varied substantially among measurements dates, whereas the pool of amino acids was relatively constant and always comprised $30-40 \%$ of the soluble non-protein N (Fig. 1). On the first three measurement dates, ammonium comprised $50-70 \%$ of the pool of soluble non-protein $\mathrm{N}$ and nitrate was 5-30\%; whereas on the final measurements date ammonium was the least abundant $\mathrm{N}$-form (10\%) and nitrate was the most abundant $\mathrm{N}$-form (70\%).

\subsection{Uptake of $\mathbf{N}$}

Rates of $\mathrm{N}$ uptake did not differ among sites $(P>0.05)$ or species $(P>0.05)$ but did differ among forms of $\mathrm{N}$ 


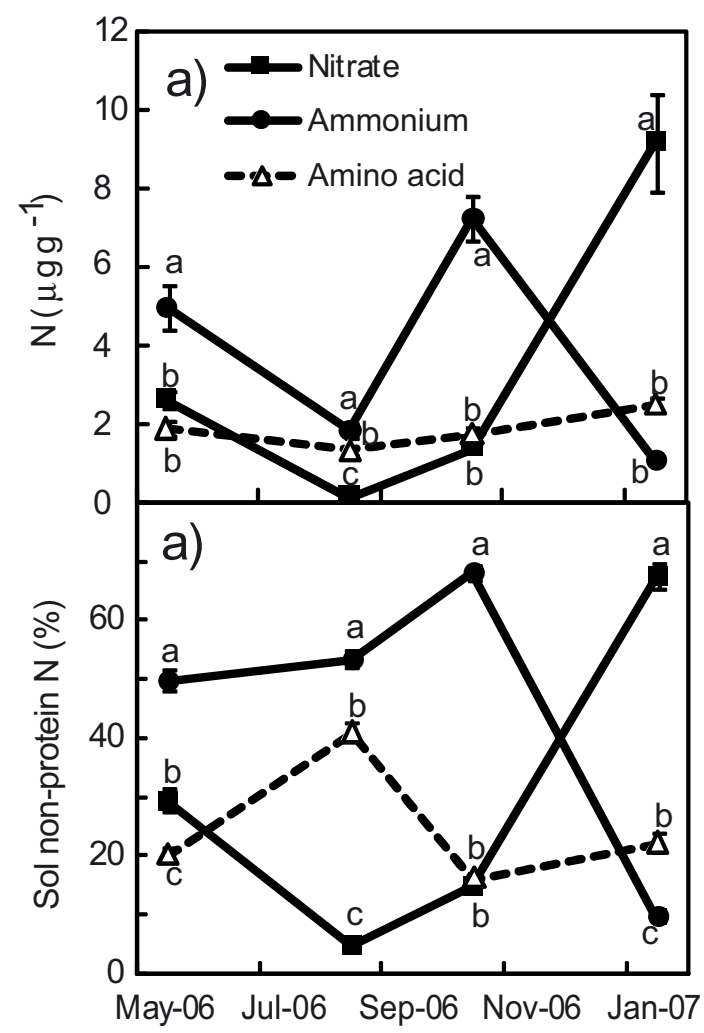

Figure 1. Absolute (a) and relative (b) concentrations of nitrate, ammonium and amino acids in $1 \mathrm{M} \mathrm{KCl}$ extracts of soil. Absolute concentrations are expressed per gram dry mass of soil. Replicate soil samples were collected adjacent to each of three Eucalyptus species at each of three sites on four occasions. Absolute and relative amounts of nitrate, ammonium and amino acids did not differ depending on which species they were collected next to (ANOVA, $P>0.05$ ), or between the three sites; hence data for species and sites are combined. Each data point is the mean of 27 replicates; error bars are standard errors. At all dates there were significant differences among $\mathrm{N}$-forms (ANOVA, $P<0.05$ ), thus the significance of differences between pairs of means was determined by a post hoc test (LSD) and is indicated by superscripted letters.

$(P<0.001)$. Uptake of ammonium $\left(6.7 \pm 0.4 \mu \mathrm{mol} \mathrm{g} \mathrm{h}^{-1}\right.$, mean $\pm \mathrm{SE}, n=108$ ) was significantly faster than glycine $\left(2.2 \pm 0.1 \mu \mathrm{mol} \mathrm{g} \mathrm{h}^{-1}\right)$ which was faster than nitrate $(0.33 \pm$ $0.08 \mu \mathrm{mol} \mathrm{g} \mathrm{h}^{-1}$ ) (Fig. 2). Preference for $\mathrm{N}$ forms did not differ among species (species $* \mathrm{~N}$-form interaction, $P>0.05$ ).

\subsection{Is glycine taken up intact?}

There was a positive relationship between amounts of ${ }^{13} \mathrm{C}$ and ${ }^{15} \mathrm{~N}$ taken up (Fig. 3). The relationship between ${ }^{13} \mathrm{C}$ and ${ }^{15} \mathrm{~N}$ taken up did not differ among species, sites or dates (ANCOVA, $P>0.05)$, and thus all data are combined. The slope of the relationship was 1.25 , versus an expected slope of 2 if all glycine were taken up as intact molecules.

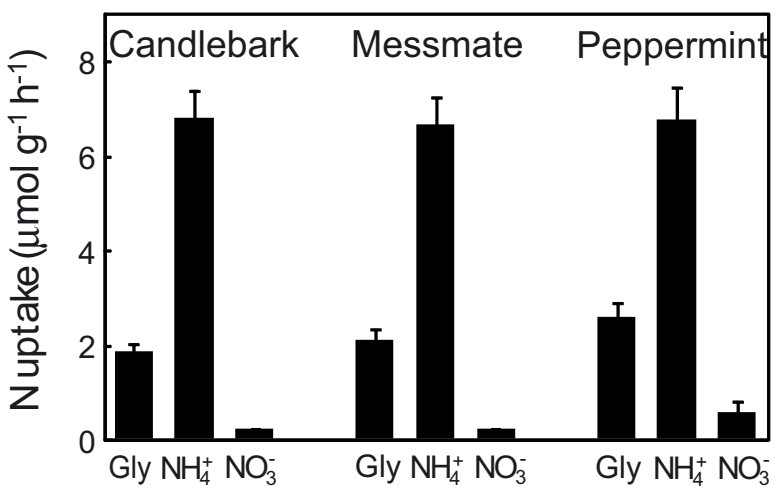

Figure 2. Rate of uptake of glycine, ammonium and nitrate by intact roots of mature trees of messmate (E. obliqua), candlebark ( $E$. rubida) and narrow-leaf peppermint ( $E$. radiata). The rate of uptake was determined by incubating intact attached roots in equimolar $\left(100 \mu \mathrm{mol} \mathrm{L}{ }^{-1}\right)$ solutions of nitrate, ammonium and glycine. Three replicate measurements were made on each of the three species at each of three sites on four occasions. There was no difference in uptake rate among sites or dates $(P>0.05)$ and thus these data are combined. Data are the mean of 36 replicates per species, and errors bars are standard error. Uptake rates differed significantly among forms of $\mathrm{N}(P<0.0001)$, but species did not vary in their preference for different forms of $\mathrm{N}$ (species* $\mathrm{N}$-form interaction, $P>0.05$ ).

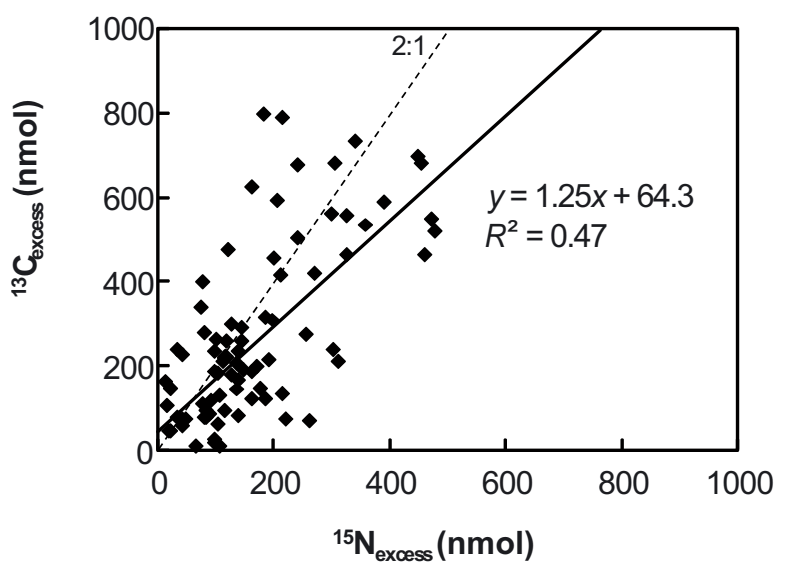

Figure 3. The relationship of ${ }^{15} \mathrm{~N}$ excess with ${ }^{13} \mathrm{C}$ excess in intact roots of mature trees of messmate (E. obliqua), candlebark (E. rubida) and narrow-leaf peppermint (E. radiata) that had been incubated in $2{ }^{13} \mathrm{C}_{2}{ }^{15} \mathrm{~N}$-glycine. Glycine uptake by the three species was measured at three sites on each of four occasions. A total of 108 measurements are shown $(3$ species $\times 3$ sites $\times 4$ dates $\times 3$ replicate trees). Relationships did not differ among dates, sites or species (ANCOVA) and thus a common relationship was fitted. Also shown is the expected 2:1 relationship if all glycine were taken up intact.

\section{DISCUSSION}

\subsection{Do co-occurring species avoid competing for N?}

Nitrogen $(\mathrm{N})$ is required in large quantities by all plants, but the supply of $\mathrm{N}$ by the soil is sometimes sub-optimal in which case plant growth is limited by $\mathrm{N}$ availability (Koerselman and Meuleman, 1996). We suspect that $\mathrm{N}$ is limiting in this 
ecosystem because the high soil C:N ratio (30-35; Warren, unpublished data) will probably lead to net immobilization of $\mathrm{N}$ by soil microbes (Hodge et al., 2000). Hence, plants ought to compete intensely for the small amounts of available $\mathrm{N}$. We found that three species of sympatric Eucalyptus occur in soil containing $\mathrm{N}$ in a variety of different chemical forms (Fig. 1), and thus the soil provides the potential for avoiding competition. However, the three species had remarkably similar preferences for forms of $\mathrm{N}$ (Fig. 2). In all species, ammonium was the preferred source of nitrogen and was taken up 2.5-4.5 times faster than glycine, and 30-50 times faster than nitrate (see also Attiwill et al., 1996; Warren, 2006). The similar preference of species for $\mathrm{N}$-forms means that (all else being equal) the three Eucalyptus species are likely to compete for N. Results of this study contrast with those showing niche differentiation based on chemical forms of $\mathrm{N}$ (e.g. McKane et al., 2002; Miller and Bowman, 2003; Miller et al., 2007; Näsholm et al., 1998; Weigelt et al., 2003; 2005), but are consistent with other studies showing that species preference for $\mathrm{N}$-forms varies little among sympatric species (Kronzucker et al., 1997; Stewart et al., 1989). Based on the general absence of agreement among studies, the only conclusion that may be reached is that niche differentiation based on chemical forms of $\mathrm{N}$ occurs in some ecosystems but not all.

Differences among studies might reflect the extent of $\mathrm{N}$ limitation among ecosystems. It may be the case that those ecosystems without niche differentiation are not limited by $\mathrm{N}$. For example, while Eucalyptus forests of Australia may respond positively to additions of $\mathrm{N}$ fertiliser, it is likely that they are primarily limited by $P$ and only secondarily or not at all by N (Attiwill and May, 2001). More generally, there is good reason to doubt the ubiquity of limitation by N. Critical re-examination of the evidence led Peter Vitousek and Robert Howarth (Vitousek and Howarth, 1991) to argue that: "nitrogen limitation is limitation by another nutrient in disguise...that phosphorus or another nutrient sets the limit for...net primary production and that nitrogen fixation then brings the availability of nitrogen near, but not to, this limit". If we follow this logic, niche differentiation by uptake of different chemical forms of $\mathrm{N}$ may be confined to those "rare" ecosystems in which $\mathrm{N}$ is truly limiting (e.g. those on very young soils or where $\mathrm{N}$ mineralisation is limited by cold temperatures).

Differing methodologies may alternatively explain the discrepancy among studies. Most studies showing similar patterns of $\mathrm{N}$ uptake among co-occurring species have estimated $\mathrm{N}$ uptake from hydrosolutions (e.g. this study, Kronzucker et al., 1997; Stewart et al., 1989), whereas most studies showing niche differentiation have estimated $\mathrm{N}$ uptake from injection of ${ }^{15} \mathrm{~N}$ into the soil (e.g. McKane et al., 2002; Näsholm et al., 1998; Weigelt et al., 2005). Hydrosolution experiments are arguably good indicators of preferred patterns of $\mathrm{N}$ uptake (i.e. the fundamental niche) because they do not involve competition of roots with soil microbes or other plant species; whereas soil experiments are better at showing actual patterns of $\mathrm{N}$ uptake (i.e. the realised niche) because they involve competition with soil microbes and other plants.

\subsection{Can the three Eucalyptus species take up glycine?}

Key to interpreting trends in $\mathrm{N}$ uptake is knowing whether glycine is taken up as glycine, or after de-amination (e.g. as ammonium). The positive relationship between uptake of ${ }^{15} \mathrm{~N}$ and ${ }^{13} \mathrm{C}$ from glycine indicates that the three Eucalyptus species have the ability to take up organic nitrogen in the form of glycine. This is consistent with previous studies showing that Eucalyptus and other Australian genera can take up amino acids (Schmidt and Stewart, 1999; Persson and Nasholm, 2001; Warren, 2006). We suggest that uptake of glycine may make a significant contribution to the $\mathrm{N}$ economy of Eucalyptus given that glycine is a common amino acid in soils from Eucalyptus forests (Schmidt and Stewart, 1999; Warren, 2006) and recent studies showed uptake of intact glycine from soil by Eucalyptus species (Warren, 2009a; 2009b).

Approximately $1.2{ }^{13} \mathrm{C}$ were taken up for every ${ }^{15} \mathrm{~N}$ from glycine, whereas the expected ratio based on the labelling of glycine was 2:1 (Fig. 3). The relationship between ${ }^{13} \mathrm{C}_{\text {excess }}$ and ${ }^{15} \mathrm{~N}_{\text {excess }}$ was rather scattered, and this may have led to deviation of the slope from the expected 2:1. Another consequence of the scattered relationship is that it may have led us to conclude erroneously that the ${ }^{13} \mathrm{C}_{\text {excess }}-{ }^{15} \mathrm{~N}_{\text {excess }}$ relationship does not differ among species and dates, whereas there are in fact true differences. If we accept that the slope of $1.3{ }^{13} \mathrm{C}:{ }^{15} \mathrm{~N}$ is correct, it implies that $60 \%$ of glycine molecules were taken up intact, which is rather similar to the percent of intact uptake reported in similar studies (Warren, 2006; Warren and Adams, 2007). Studies with other Eucalyptus species have measured uptake of intact glycine molecules by GC-MS (Warren, 2009a; $2009 \mathrm{~b}$ ) and thus it is unlikely that the correlation of ${ }^{13} \mathrm{C}$ and ${ }^{15} \mathrm{~N}$ reflects soil mineralisation of glycine to inorganic compounds $\left({ }^{15} \mathrm{NO}_{3-},{ }^{15} \mathrm{NH}_{4}+,{ }^{13} \mathrm{CO}_{2}\right)$ that are subsequently taken up by plants (Jones et al., 2005). The other $40 \%$ of glycine molecules may have been taken up intact then metabolised to serine with subsequent loss of ${ }^{13} \mathrm{C}$ (Näsholm et al., 2000), or glycine- $\mathrm{N}$ may have been taken up after mineralisation. Collectively these findings suggest that the bulk of glycine- $\mathrm{N}$ is taken up as intact molecules of glycine.

Acknowledgements: This work was supported by Discovery Grant funding from the Australian Research Council. We wish to thank Kath Whittaker, Loris Duclos, Matt Lee, Frank Jones and Najib Ahmady for assistance in the laboratory and field.

\section{REFERENCES}

Attiwill P.M. and May B.M., 2001. Does nitrogen limit the growth of native eucalypt forests: some observations for mountain ash (Eucalyptus regnans). Mar. Freshw. Res. 52: 111-117.

Attiwill P.M., Polglase P.J., Weston C.J., and Adams M.A., 1996. Nutrient cycling in forests of south-eastern Australia. In: Attiwill P.M. and Adams M.A. (Eds.), Nutrition of eucalypts, CSIRO, Melbourne, pp. 191-228.

Chapin F.S., Moilanen L., and Kielland K., 1993. Preferential use of organic nitrogen for growth by a nonmycorrhizal Arctic sedge. Nature 361: $150-153$. 
Gessler A. et al., 1998. Field and laboratory experiments on net uptake of nitrate and ammonium by the roots of spruce (Picea abies) and beech (Fagus sylvatica) trees. New Phytol. 138: 275-285.

Henry H.A.L. and Jefferies R.L., 2003. Interactions in the uptake of amino acids, ammonium and nitrate ions in the Arctic salt-marsh grass, Puccinellia phryganodes. Plant Cell Environ. 26: 419-428.

Hodge A., Robinson D., and Fitter A., 2000. Are microorganisms more effective than plants at competing for nitrogen? Trends Plant Sci. 5: 304-308.

Hutchinson G.E., 1959. Homage to Santa-Rosalia or why are there so many kinds of animals. Am. Nat. 93: 145-159.

Jones D.L., Healey J.R., Willett V.B., Farrar J.F., and Hodge A., 2005. Dissolved organic nitrogen uptake by plants - an important $\mathrm{N}$ uptake pathway? Soil Biol. Biochem. 37: 413-423.

Kamminga-Van Wijk C. and Prins H.B.A., 1993. The Kinetics of $\mathrm{NH}_{4}^{+}$ and $\mathrm{NO}_{3}^{-}$Uptake by Douglas-Fir from Single N-Solutions and from Solutions Containing Both $\mathrm{NH}_{4}^{+}$and $\mathrm{NO}_{3}^{-}$. Plant Soil 151: 91-96.

Koerselman W. and Meuleman A.F.M., 1996. The vegetation N:P ratio: A new tool to detect the nature of nutrient limitation. J. Appl. Ecol. 33: $1441-1450$.

Kronzucker H.J., Siddiqi M.Y., and Glass A.D.M., 1997. Conifer root discrimination against soil nitrate and the ecology of forest succession. Nature 385: 59-61.

Lipson D.A., Raab T.K., Schmidt S.K., and Monson R.K., 1999. Variation in competitive abilities of plants and microbes for specific amino acids. Biol. Fertil. Soils 29: 257-261.

Lucash M.S., Eissenstat D.M., Joslin J.D., McFarlane K.J., and Yanai R.D., 2007. Estimating nutrient uptake by mature tree roots under field conditions: challenges and opportunities. Trees Struct. Funct. 21: 593-603.

MacArthur R. and Levins R., 1967. Limiting similarity convergence and divergence of coexisting species. Am. Nat. 101: 377-385.

McKane R.B. et al., 2002. Resource-based niches provide a basis for plant species diversity and dominance in Arctic tundra. Nature 415: 68-71.

Miller A.E. and Bowman W.D., 2003. Alpine plants show species-level differences in the uptake of organic and inorganic nitrogen. Plant Soil 250: 283-292.

Miller A.E., Bowman W.D., and Suding K.N., 2007. Plant uptake of inorganic and organic nitrogen: neighbor identity matters. Ecol. Lett. 88: $1832-1840$.

Näsholm T., Ekblad A., Nordin A., Giesler R., Högberg M., and Högberg P., 1998. Boreal forest plants take up organic nitrogen. Nature 392: 914-916.

Näsholm T., Huss-Danell K., and Hogberg P., 2000. Uptake of organic nitrogen in the field by four agriculturally important plant species. Ecology 81: 1155-1161.
Parrish J.A.D. and Bazzaz F.A., 1976. Underground niche separation in successional plants. Ecology 57: 1281-1288.

Persson J., Gardestrom P., and Nasholm T., 2006. Uptake, metabolism and distribution of organic and inorganic nitrogen sources by Pinus sylvestris. J. Exp. Bot. 57: 2651-2659.

Schimel J.P. and Bennett J., 2004. Nitrogen mineralization: challenges of a changing paradigm. Ecology 85: 591-602.

Schobert C. and Komor E., 1987. Amino Acid Uptake by Ricinus communis Roots - Characterization and Physiological Significance. Plant Cell Environ. 10: 493-500.

Stewart G.R., Pearson J., Kershaw J.L., and Clough E.C.M., 1989. Biochemical aspects of inorganic nitrogen assimilation by woodyplants. Ann. Sci. For. 46: S648-S653.

Tolhurst K. and Flinn D., 1992. Ecological impacts of fuel reduction burning in dry sclerophyll forest: first progress report. Department of Conservation and Environment, Melbourne.

Tomkins I.B., Kellas J.D., Tolhurst K.G., and Oswin D.A., 1991. Effects of fire intensity on soil chemistry in a eucalypt forest. Aust. J. Soil Res. 29: 25-47.

Vitousek P.M. and Howarth R.W., 1991. Nitrogen limitation on land and in the sea - how can it occur. Biogeochemistry 13: 87-115.

Warren C.R., 2006. Potential organic and inorganic N uptake by six Eucalyptus species. Funct. Plant Biol. 33: 653-660.

Warren C.R., 2008. Rapid and sensitive quantification of amino acids in soil extracts by capillary electrophoresis with laser-induced fluorescence. Soil Biol. Biochem. 40: 916-923.

Warren C.R., 2009a. Uptake of inorganic and amino acid Nitrogen from soil by Eucalyptus regnans and Eucalyptus pauciflora seedlings. Tree Physiol. 29: 401-409.

Warren C.R., 2009b. Why does temperature affect relative uptake rates of nitrate, ammonium and glycine: A test with Eucalyptus pauciflora. Soil Biol. Biochem. 41: 778-784.

Warren C.R. and Adams P.R., 2007. Uptake of nitrate, ammonium and glycine by plants of Tasmanian wet eucalypt forests. Tree Physiol. 27: 413-419.

Weigelt A., King R., Bol R., and Bardgett R.D., 2003. Inter-specific variability in organic nitrogen uptake of three temperate grassland species. J. Plant Nutrit. Soil Sci. 166: 606-611.

Weigelt A., Bol R., and Bardgett R.D., 2005. Preferential uptake of soil nitrogen forms by grassland plant species. Oecologia 142: 627-635.

Wright D.E., 1962. Amino acid uptake by plant roots. Arch. Biochem. Biophys. 97: 174-180. 